\title{
Brain-Derived Neurotrophic Factor, Neurotrophin-3, and Neurotrophin-4 Complement and Cooperate with Each Other Sequentially during Visceral Neuron Development
}

\author{
Wael M. EIShamy and Patrik Ernfors \\ Department of Medical Biochemistry and Biophysics, Laboratory of Molecular Neurobiology, Doktorsingen 12A, \\ Karolinska Institute, 17177 Stockholm, Sweden
}

The neurotrophins nerve growth factor (NGF), brain-derived neurotrophic factor (BDNF), neurotrophin-3 (NT3), and neurotrophin-4 (NT4) are crucial target-derived factors controlling the survival of peripheral sensory neurons during the embryonic period of programmed cell death. Recently, NT3 has also been found to act in a local manner on somatic sensory precursor cells during early development in vivo. Culture studies suggest that these cells switch dependency to NGF at later stages. The neurotrophins acting on the developing placodederived visceral nodose/petrosal (N/P) ganglion neurons are BDNF, NT3, and NT4. To assess their roles in development, we analyzed embryonic development in mice carrying a deletion in each of these genes, or combinations of them, and found that they are essential in preventing the death of N/P ganglion neurons during different periods of embryogenesis. Both NT3 and NT4 are crucial during the period of ganglion formation, whereas BDNF acts later in development. Many, but not all, of the NT3- and NT4-dependent neurons switch to BDNF at later stages. We conclude that most of the N/P ganglion neurons depend on more than one neurotrophin and that they act in a complementary as well as a collaborative manner in a developmental sequence for the establishment of a full complement of visceral neurons.

Key words: neurotrophins; nodose/petrosal; precursor cells; survival; development; programmed cell death
The neurotrophin family of neurotrophic factors in mammals includes nerve growth factor (NGF) (Levi-Montalcini, 1987), brainderived neurotrophic factor (BDNF) (Barde et al., 1982; Leibrock et al., 1989), neurotrophin-3 (NT3) (Ernfors et al., 1990; Hohn et al., 1990; Jones and Reichardt, 1990; Kaisho et al., 1990; Maisonpierre et al., 1990a,b; Rosenthal et al., 1990), and NT4 (Hallböök et al., 1990; Berkemeier et al., 1991; Ip et al., 1992). They act as target-derived trophic factors that elicit survival-promoting effects during the developmental period of programmed cell death, and recent years of research have uncovered a remarkable specificity of neurotrophins in the support of different functional classes of dorsal root, trigeminal, vestibular, and auditory ganglion neurons (Hohn et al., 1990; Hory-Lee et al., 1993; Coggeshall et al., 1994; Ernfors et al., 1994a; Farinas et al., 1994; Klein et al., 1994; Arvidsson et al., 1995; Ernfors et al., 1995; Gesine and Davies, 1995; Oakley et al., 1995; Airaksinen et al., 1996; ElShamy and Ernfors, 1996a,b). NT3 has also been suggested to play a role for somatic sensory neurons before the period of programmed cell death affecting survival and differentiation (Kalcheim et al., 1992; Wright et al., 1992; Gaese et al., 1994; Memberg and Hall, 1995; ElShamy and Ernfors, 1996a,b; Farinas et al., 1996).

In this study we have examined the role of neurotrophins in the embryonic development of the autonomic nodose/petrosal (N/P) ganglion. This ganglion is formed from the migration of placode-

Received June 30, 1997; revised Aug. 11, 1997; accepted Aug. 26, 1997.

This research was supported by the Swedish Medical Research Council, the Swedish Cancer Society, and Petrus, Augusta Hedlunds Foundation. We thank Lena Klevenvall-Fridvall for technical assistance and Lotta Johansson for secretarial assistance.

Correspondence should be addressed to Dr. Patrik Ernfors, Department of Medical Biochemistry and Biophysics, Laboratory of Molecular Neurobiology, Doktorsringen 12A, Karolinska Institute, 17177 Stockholm, Sweden.

Copyright (C) 1997 Society for Neuroscience $0270-6474 / 97 / 178667-09 \$ 05.00 / 0$ derived cells during embryonic day (E) 10.5 in the mouse (Morin et al., 1997), and neurogenesis occurs between E11 and E15 in the rat (corresponding to E9-E13 in the mouse), with a peak at E14 (Altman and Bayer, 1982). Peripheral afferents of the N/P ganglion innervate the viscera of the body, the smooth muscle of the heart, the lungs, blood vessels, carotid body, and some taste buds. Culture studies and neurotrophin receptor expression mapping suggested that developing $\mathrm{N} / \mathrm{P}$ ganglion neurons depend on BDNF, NT3, and NT4 but not NGF (Davies and Lindsay, 1985; Lindsay and Rohrer, 1985; Lindsay et al., 1985; Ernfors et al., 1992; Buj-Bello et al., 1994; Thaler et al., 1994). Consistently, a reduction of $43 \%$ in volume and $57-66 \%$ in N/P ganglion neuronal numbers in $b d n f^{-1-}$ mice (Ernfors et al., 1994b; Jones et al., 1994; Conover et al., 1995; Liu et al., 1995), 30-47\% in mice lacking $n t 3$ (Ernfors et al., 1994a; Farinas et al., 1994), and 59-61\% in mice lacking nt4 (Conover et al., 1995; Liu et al., 1995) have been reported at birth. Furthermore, the neuronal loss of petrosal ganglion cells after removal of a target, the carotid body, can be prevented by exogenous application of BDNF (Hertzberg et al., 1994).

We have analyzed the $\mathrm{N} / \mathrm{P}$ ganglion neuron dependence on neurotrophins in mice lacking BDNF, NT3, and NT4 and in double-mutant mice during embryonic development. Our results suggest that BDNF, NT3, and NT4 act in a complementary and collaborative manner to generate a full complement of visceral neurons.

\section{MATERIALS AND METHODS}

Animals. Embryos were obtained from crosses of heterozygous mice or double-heterozygous mice carrying the null mutated alleles for $b d n f$ (Ernfors et al., 1994b), nt3 (Ernfors et al., 1994a), or $n t 4$ (Liu et al., 1995), and the day of the vaginal plug was considered as E0. Pregnant females were injected intraperitoneally with 5-bromodeoxyuridine (BrdU) (Sig- 
ma, St. Louis, MO; $50 \mathrm{mg} / \mathrm{kg}$ or $200 \mathrm{mg} / \mathrm{kg}$ ), and embryos (days 10, 11, 12,14 , and 17 of gestation) and postnatal day (P) 0 and $\mathrm{P} 7$ mice were collected 5-6 hr later, immersion-fixed in 4\% paraformaldehyde (PFA) for $2 \mathrm{hr}$ to overnight, sucrose-embedded, frozen on dry ice, and sectioned at $15 \mu \mathrm{m}$ on a cryostat. The mice were genotyped for the wild-type and inactive alleles of the $b d n f, n t 3$, or $n t 4$ genes by PCR.

Neuronal counts. Sections were stained with cresyl violet. The number of neurons in the N/P ganglion with a clear nucleus and nucleoli was counted in every sixth section. The total number of neurons $(N)$ was estimated by multiplying the counted number of profiles $(n)$ with a factor derived from dividing the thickness $(T)$ of the counted sections by $T$ plus the average diameter of the nuclei $(D): n=n \times T / T+D$ (Abercrombie, 1946).

Detection of dying cells. Dying cells were stained using the terminal dUTP nick end labeling (TUNEL) technique using the ApopTag in situ apoptosis detection kit (Oncor, Gaithersburg, MD) according to the manufacturer's instructions. The number of apoptotic cells was counted in every sixth section through the entire ganglion [ E11: wild-type $(w / t)$, $6 ; b d n f^{-1-}, 6 ; \mathrm{nt}^{2} \mathrm{t}^{-1-}, 6 ; \mathrm{nt}^{-1-}, 4$. E12: w/t, $6 ; b d n f^{-1-}, 6 ; \mathrm{nt}^{-/-}, 6$; nt4 ${ }^{-1-}, 8$. E14: $w / t, 6 ; b d n f^{-1-}, 8 ; \mathrm{nt}^{-1-}, 4 ; \mathrm{nt} 4^{-1-}, 8$. E17: $w / t, 6$; $\left.b d n f^{-1-}, 4 ; \mathrm{nt}^{-1-}, 4 ; \mathrm{nt} 4^{-1-}, 4\right]$.

Immunohistochemistry. For analysis of proliferation, the cells that had incorporated $\mathrm{BrdU}$ were stained by immunohistochemistry. The sections were post-fixed for $15 \mathrm{~min}$ in $4 \%$ PFA, washed $3 \times 5 \mathrm{~min}$ in PBS, incubated in $2 \mathrm{M} \mathrm{HCl}$ in $70 \%$ ethanol at $-20^{\circ} \mathrm{C}$ for $10 \mathrm{~min}$, and drained, and endogenous peroxidase activity was blocked in $2 \%$ hydrogen peroxide in PBS for $5 \mathrm{~min}$ at room temperature and rinsed in PBS $(3 \times 5 \mathrm{~min})$. The sections were then deproteinized in ice-cold $0.1 \mathrm{M} \mathrm{HCl}$ for $20 \mathrm{~min}$, denatured with $2 \mathrm{M} \mathrm{HCl}$ in PBS for $30 \mathrm{~min}$, then neutralized in $0.1 \mathrm{M}$ borate buffer, $\mathrm{pH} 8.5$, for $10 \mathrm{~min}$, rinsed twice in PBS for $10 \mathrm{~min}$, and blocked for $1 \mathrm{hr}$ in blocking solution (10\% goat serum, $0.1 \%$ Tween-20 in PBS). The sections were then incubated overnight with a mouse anti-BrdU antibody (Sigma) diluted 1:500 in blocking solution. The sections were washed $4 \times 15 \mathrm{~min}$ in PBS containing $0.1 \%$ Tween- 20 and incubated for $4 \mathrm{hr}$ with a peroxidase-conjugated goat anti-mouse secondary antibody (1:200) (Dako, Glöstrup, Denmark). After $4 \times 15 \mathrm{~min}$ washes in PBS, the sections were developed with 3-3'-diaminobenzidine (DAB) (Sigma). The DAB $(10 \mathrm{mg})$ was dissolved in $50 \mathrm{ml}$ of $100 \mathrm{~mm}$ Tris, $\mathrm{pH} 7.5$, containing $0.05 \%$ nickel chloride. The number of BrdUpositive cells was counted in every sixth section for the entire ganglion (E11: $w / t, 6 ; b d n f^{-1-}, 4 ; \mathrm{nt}^{-1-}, 6 ; \mathrm{nt}^{-1-}, 4 . \mathrm{E} 12: w / t, 8 ; b d n f^{-1-}, 6$; nt3 $3^{-1-}, 6 ; \mathrm{nt}^{-1-}, 6$. E14: w/t, $8 ; b d n f^{-1-}, 6 ; \mathrm{nt}^{-1-}, 6 ; \mathrm{nt}^{-1-}, 6$. E17: $w / t$, 4; $\left.b d n f^{-l-}, 4 ; \mathrm{nt}^{-/-}, 4 ; \mathrm{nt}^{-l-}, 4\right)$.

Proliferating cell nucleus antigen (PCNA) immunostaining. In brief, sections from $w / t$ and $n t 3^{-1-}$ mice at E11 and E12 $(n=4$ for each stage $)$ were treated for $10 \mathrm{~min}$ with $70 \%$ ethanol in $2 \mathrm{M} \mathrm{HCl}$, fixed with acetone for $20 \mathrm{~min}$ in $-20^{\circ} \mathrm{C}$, and then treated twice with methanol for $10 \mathrm{~min}$ in room temperature; the endogenous peroxidase activity was blocked by the addition of $2 \%$ hydrogen peroxide during the last $10 \mathrm{~min}$ in methanol. The sections were washed in PBS for $3 \times 15 \mathrm{~min}$, incubated for $1 \mathrm{hr}$ in blocking buffer containing $5 \%$ goat serum, $5 \%$ bovine serum albumin, and $0.1 \%$ Tween-20 in PBS, and then incubated overnight with mouse anti-PCNA (Santa Cruz Biotechnology, Tebu, France) (1:50) in blocking buffer. After primary antibody, the sections were washed and then incubated with a biotinylated goat anti-mouse secondary antibody in PBS with $0.1 \%$ Tween-20 (1:200) (Vector Laboratories, Burlingame, CA); immunostaining was visualized with the Vector Laboratory ABC immunoperoxidase-kit, using DAB intensified with nickel chloride as substrate.

Tyrosine hydroxylase (TH)-immunohistochemistry. After post-fixation in $4 \%$ PFA and washes in PBS, the sections were treated $3 \times 15$ min with $50 \%$ ethanol in PBS, and $2 \%$ of hydrogen peroxide was added during the last $10 \mathrm{~min}$. The sections were then washed in PBS and blocked for $1 \mathrm{hr}$ in blocking buffer containing $10 \%$ goat serum and $0.1 \%$ Tween-20 in PBS. The sections were incubated with an anti-rabbit TH antiserum (1:500) (Pel-Freez Biologicals, Rogers, AR) in blocking buffer overnight. After primary antibody, sections were treated as described for PCNA immunohistochemistry ( $n=4$ at each time point examined).

\section{RESULTS}

\section{NT3 and NT4 act early and BDNF acts late in the development of the N/P ganglion}

To establish whether neurotrophins act at different periods in development of the N/P ganglion, cresyl violet-stained sections were prepared at several embryonic and postnatal stages through the $\mathrm{N} / \mathrm{P}$ ganglion of $b d n f^{-1-}, n t 3^{-/-}, n t 4^{-/-}$, and age-matched wild-type mice. Visual examination of the $\mathrm{N} / \mathrm{P}$ ganglion revealed a clear reduction in the size of the ganglion of $n t 3^{-1-}$ and $n t 4^{-/-}$mice at E14, and in all single- and double-mutant mice at P0 (Fig. 1). Neuronal numbers were quantitatively measured from E11 to P0 (Table 1). In the $n t 3^{-1-}$ mice a normal complement of neurons was found at E11 (Table 1). Between E11 and E14 a marked reduction in neuronal numbers could be detected (40\% loss) (Table 1, Fig. 2). No significant change could be detected between E14 and P0 (Table 1). The total loss observed in $n t 3^{-1-}$ mice amounted to $41 \%$ at P0. NT4 was also found to act at early times of N/P ganglion development, although the loss was more sudden (Fig. 2). Minor neuronal loss was found in $n t 4^{-1-}$ mice before E12; between E12 and E14 there was a marked reduction in the number of neurons (Table 1, Fig. 2). No significant changes occurred between E14 and P0. The total loss of neurons at P0 in $n t 4^{-1-}$ mice was $57 \%$ (Table 1 ). Because of the sudden loss between E12 and E14 in the $n t 4^{-/-}$mice, we generated E13 $n t 4^{-1-}$ mice. Interestingly, although neuronal numbers increased between E12 and E13 in the wild-type mice, numbers found at E13 were similar to those at E12 in the $n t 4^{-/-}$mice. A further reduction in the neuronal numbers was detected between E13 and E14 in $n t 4^{-1-}$ mice (Table 1). In contrast to $n t 3^{-1-}$ and $n t 4^{-/-}$mice, the loss of neurons occurred more progressively and at significantly later developmental stages in $b d n f^{-1-}$ mice. Although $24 \%$ of the neurons were absent at E14, the majority of the neuronal loss occurred between E14 and birth (a further 35\% reduction, compared with agematched controls) (Table 1, Fig. 2). The total decrease in neurons in the $b d n f^{-1-}$ mice was found to be $59 \%$ at P0. Thus, these findings show that whereas NT3 and NT4 act during early embryonic stages, BDNF acts mostly at later time points in the development of the $\mathrm{N} / \mathrm{P}$ ganglion.

\section{Cells are depleted in the N/P ganglion of neurotrophin mutant mice because of excessive apoptosis}

To establish whether the reduction in neuronal numbers was caused by excessive cell death, serial sections of $\mathrm{N} / \mathrm{P}$ ganglion were processed for TUNEL staining, which labels dying cells. An elevation in cell death was already detected at E11 in $n t 3^{-1-}$ mice, compared with age-matched control mice (207\% of control), and remained increased also at E12 (222\% of control) (Figs. $3,4)$. Similar to that of $n t 3^{-/-}$mice, a pronounced increase of apoptosis in $n t 4^{-1-}$ mice occurred at E12 (193\% of control), whereas no significant excessive cell death could be found at E11, E14, or E17 (Figs. 3, 4). In contrast to $n t 3^{-1-}$ and $n t 4^{-1-}$ mice, excessive cell death was only minor at E11 and E12 in $b d n f^{-/-}$ mice. Instead, elevated apoptosis was seen at E14 and E17 in $b d n f^{-1-}$ mice $(132 \%$ and $140 \%$ of control mice, respectively) (Figs. 3, 4). Thus, these findings show that the loss of N/P ganglion neurons is caused by excessive cell death occurring at specific embryonic periods in the different neurotrophin mutant mice.

\section{Proliferation in the N/P ganglion of neurotrophin mutant mice}

The early loss of neurons in the $n t 3^{-1-}$ and $n t 4^{-1-}$ mice opened up the possibility that these neurotrophins influence the proliferating N/P ganglion precursor cells. Pregnant females from crosses of heterozygous neurotrophin mutant mice were therefore in- 

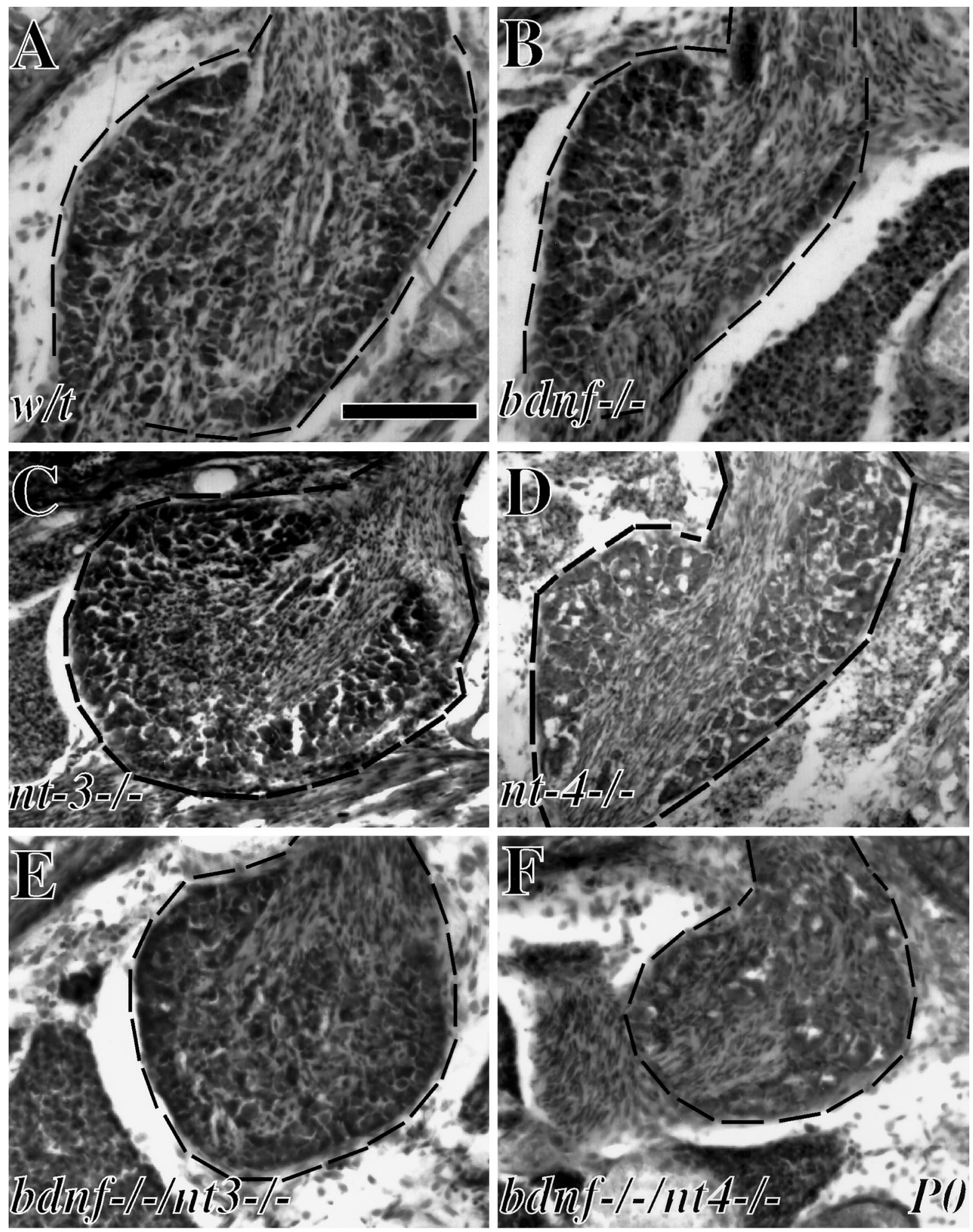

Figure 1. Photomicrographs of cresyl violet sections through the N/P ganglion (outlined with dashed line) of $\mathrm{P} 0(A)$ wild-type, $(B) b d n f^{-/-},(C) n t 3^{-/}$ (D) $n t 4^{-1-},(E) b d n f^{-1-} / n t 3^{-1-}$, and $(F) b d n f^{-1-} / n t 4^{-1-}$ mice. Note the reduction in size in $b d n f^{-1-}, n t 3^{-1-}$, and $n t 4^{-/-}$mice, and a further reduction in $b d n f^{-1-} / n t 4^{-1-}$ mice. There was only a minor size difference in $b d n f^{-1-} n t 3^{-1-}$ mice compared with $b d n f^{-1-}$ mice. Scale bar, $100 \mu \mathrm{m}$.

jected with BrdU before the embryos were dissected, and prepared sections were stained for the detection of incorporated BrdU by immunohistochemistry. The peak of N/P neurogenesis occurs at E13-E14 in the rat (Altman and Bayer, 1982). A peak in the number of BrdU-positive cells was seen at E12, represent- ing the birth of the majority of the N/P ganglion neurons in the mouse (Fig. 5). These results agree with the previous study on the rat, taking into account that the development of the rat embryo is advanced 1-2 d compared with the mouse. Most cells born at later stages could represent the non-neuronal neural crest-derived sat- 


\begin{tabular}{llllll}
\hline \multicolumn{5}{l}{ Table 1. Neuronal numbers at different embryonic stages in wild-type and mutant mice } \\
& E11 & E12 & E13 & E14 & P0 \\
\hline$w / t$ & $1486 \pm 74$ & $3048 \pm 110$ & $5267 \pm 78$ & $3977 \pm 142$ & $4033 \pm 56$ \\
& $(n=6)$ & $(n=11)$ & $(n=4)$ & $(n=10)$ & $(n=16)$ \\
$b d n f^{-/-}$ & $1373 \pm 38$ & $2702 \pm 96$ & n.d. & $3032 \pm 63$ & $1661 \pm 81^{c}$ \\
& $(n=4)$ & $(n=4)$ & & $(n=4)$ & $(n=8)$ \\
$n t 3^{-/-}$ & $1591 \pm 102$ & $2432 \pm 127^{a}$ & n.d. & $2385 \pm 63^{b}$ & $2361 \pm 65^{c}$ \\
& $(n=6)$ & $(n=6)$ & & $(n=5)$ & $(n=6)$ \\
$n t 4^{-/-}$ & $1339 \pm 56$ & $2733 \pm 80$ & $2526 \pm 163^{b}$ & $1863 \pm 99^{c}$ & $1724 \pm 33^{c}$ \\
& $(n=10)$ & $(n=9)$ & $(n=6)$ & $(n=12)$ & $(n=8)$
\end{tabular}

Number of neurons in the N/P ganglion of mice from $w / t, b d n f^{-/-}, n t 3^{-/-}$, and $n t 4^{-/-}$genotypes at indicated developmental stages $( \pm \mathrm{SEM}) . n=$ number of ganglia counted at each indicated time point. Student's $t$ test. ${ }^{a} p<0.05 ;{ }^{b} p<0.01 ;{ }^{c} p<$ 0.001. n.d., Not determined.

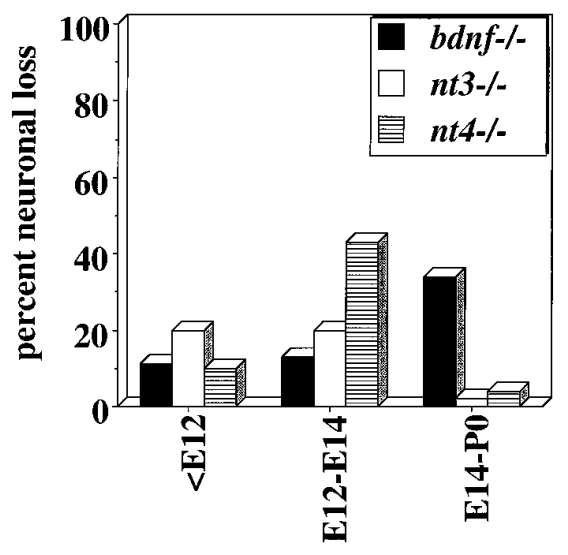

Figure 2. Percent neuronal loss compared with age-matched control mice in the N/P ganglion at different developmental periods. Note that in the $n t 3^{-/-}$mice the loss was pronounced at stages before E12, as well as between E12 and E14. In $n t^{-/-}$mice the loss was sudden, occurring mostly between E12 and E14. In $b d n f^{-1-}$ mice there was only a minor deficit before E14, but a marked loss was seen between E14 and P0.

ellite cells of the ganglion (Harrison et al., 1995). The examination of BrdU-stained sections from neurotrophin mutant mice revealed a reduced number of stained cells in the $\mathrm{N} / \mathrm{P}$ ganglion of $n t 3^{-/-}$mice at E12 and $n t 3^{-/-}$and $n t 4^{-/-}$mice at E14, whereas no difference could be seen in $b d n f^{-/-}$mice (Fig. $5 A-C$ ). Results similar to those seen with BrdU staining in the $n t 3^{-/-}$mice were seen using immunohistochemistry to detect the PCNA (Fig. 5D). The reduction in the number of proliferating cells in the $n t 3^{-/-}$ mice at E12 indicates that NT3 acting on proliferating precursor cells could contribute to the neuronal deficit, whereas BDNF and NT4 does not seem to affect the neurogenic precursor cells.

We have used $200 \mathrm{mg} / \mathrm{kg}$ BrdU in this study to detect proliferating cells using the anti-BrdU immunohistochemistry. Concentrations higher than $400 \mathrm{mg} / \mathrm{kg}$ can induce neuronal pyknosis in the embryo (Yoshida et al., 1987). To control for that the administered concentration of BrdU in this study and in our previous studies (ElShamy and Ernfors, 1996a,b) has not been toxic we counted the number of TUNEL-positive cells in the N/P ganglion at several embryonic stages of wild-type mice receiving either 200 or $50 \mathrm{mg} / \mathrm{kg}$ BrdU. The quantitation revealed very similar numbers of TUNEL-positive cells between the groups at E11 and E17. Although not significant, a slight increase was seen at E14 in the $200 \mathrm{mg} / \mathrm{kg}$ group.

\section{BDNF is required for the survival but not the differentiation of TH-positive N/P ganglion neurons}

BDNF has previously been shown to be crucial for the THpositive population of $\mathrm{N} / \mathrm{P}$ ganglion neurons involved in the control of ventilation, as displayed by a reduced number of TH-immunoreactive neurons present postnatally (Erickson et al., 1996). To investigate whether BDNF is important for the establishment or maintenance of TH-positive neurons, we counted the number of immunopositive cells at E12, E14, and E17 and at birth. Analysis of control mice indicated that these cells differentiated mainly between E12 and E14 (Table 2). There was no significant difference in the number of TH-positive neurons of $n t 3^{-1-}$ and $n t 4^{-1-}$ mice at any of the analyzed stages compared with control mice. $b d n f^{-1-}$ mice displayed an increase in $\mathrm{TH}$ positive neurons between E12 and E14, similar to control mice. However, between E14 and P0 there was a significant loss of 45\% of the TH-positive neurons. Thus, a normal complement of $\mathrm{TH}$ positive neurons were established in the $b d n f^{-1-}$ mice, but these were subsequently lost at later stages, indicating that BDNF is required for their survival but not for differentiation.

\section{Developmental switch in neurotrophin dependency of N/P ganglion neurons}

Our results indicate that neurotrophins act on the $\mathrm{N} / \mathrm{P}$ ganglion neurons at different stages of embryogenesis. This opened up the possibility that they could act in a developmental sequence to promote the generation of the $\mathrm{N} / \mathrm{P}$ ganglion, as has been described previously for NGF-dependent neurons in culture (Buchman and Davies, 1993; Buj-Bello et al., 1994). To examine this possibility, double-knockout mice were generated (Table 3). The following observations were made from the analysis of such mice.

The concentration of BDNF present in development appeared more crucial to neuronal survival than that of NT4 (Erickson et al., 1996), because $65 \%$ of the neurons remained in mice carrying only one functional $b d n f$ allele $(+/-$ mice) and $82 \%$ remained in $n t 4^{+/-}$mice. Also, the levels of NT3 appeared crucial, because there was a marked loss of $\mathrm{N} / \mathrm{P}$ ganglion neurons in $n t 3^{+/-}$mice. In fact, the majority of the neurons absent in the $n t 3^{-1-}$ mice were already eliminated by removing one of the $n t 3$ alleles.

The minor additional neuronal loss in $b d n f / n t 3$ doubleknockout mice compared with single $b d n f^{-1-}$ mice (34\% and $41 \%$ remaining of the normal complement, respectively) indicates that the majority of BDNF-dependent neurons also require NT3. Because we find that they act at different developmental stages, BDNF-dependent neurons seem to require NT3 at earlier stages. The partial additive loss in $b d n f / n t 4$ double-mutant mice $(18 \%$ 

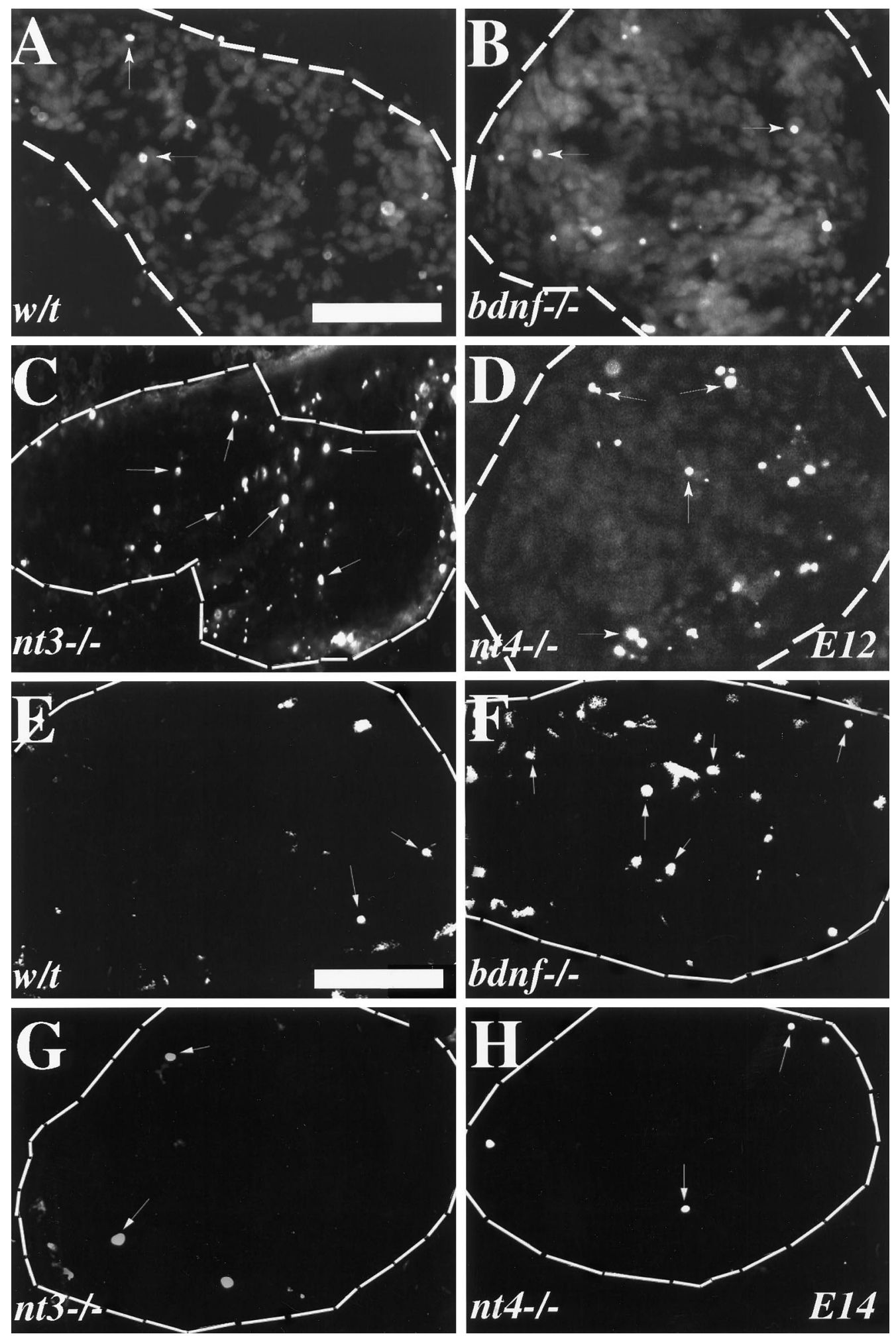

Figure 3. Apoptosis in the N/P ganglion as detected by TUNEL-staining of wild-type $(w / t) b d n f^{-/-}, n t 3^{-/-}$, or $n t 4^{-1-}$ mice. Photomicrographs of E12 $(A) w / t,(B) b d n f^{-1-},(C) n t 3^{-1-}$, and $(D) n t 4^{-1-}$ ganglia. Note the numerous apoptotic cells (arrows) in the $n t 3^{-1-}$ and $n t 4^{-1-}$ ganglia compared with $w / t$ and $b d n f^{-/-}$ganglia. Photomicrographs at E14 $(E) w / t,(F) b d n f^{-/-},(G) n t 3^{-/-}$, and $(H) n t 4^{-/-}$ganglia. Note the pronounced apoptosis in the $b d n f^{-1-}$ ganglion compared with the $w / t$. Arrows indicate arbitrarily some of the stained cells. Scale bar, $100 \mu \mathrm{m}$.

remaining) compared with single-mutant mice (41\% or $42 \%$ remaining) combined with the fact that BDNF and NT4 act at different stages suggests that a large number of the NT4dependent cells may switch dependence to BDNF at later stage.
The remaining $15-20 \%$ of neurons in the $b d n f / n t 4$ doublemutant mice represent those that depend exclusively on NT3, and the $34 \%$ that remain in $b d n f / n t 3$ double-knockout mice represent those that depend on NT4. 

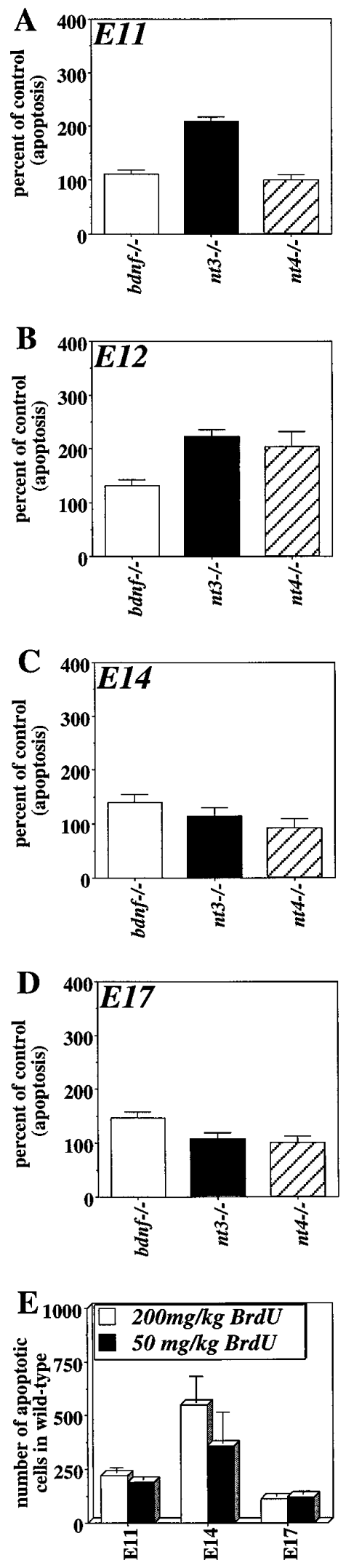

Figure 4. Percent of control $\mathrm{TUNEL}^{+}$cells in the N/P ganglion of $b d n f^{-1-}, n t 3^{-1-}$, and $n t 4^{-1-}$ mice at several embryonic stages. $A$, At E11 excessive cell death could be detected only in $n t 3^{-1-}$ mice. $B$, At E12 both $n t 3^{-1-}$ and $n t 4^{-1-}$ mice displayed excessive cell death. $C, D$, At E14 and E17 increased apoptosis was seen only in the $b d n f^{-1-}$ ganglion. $E$,
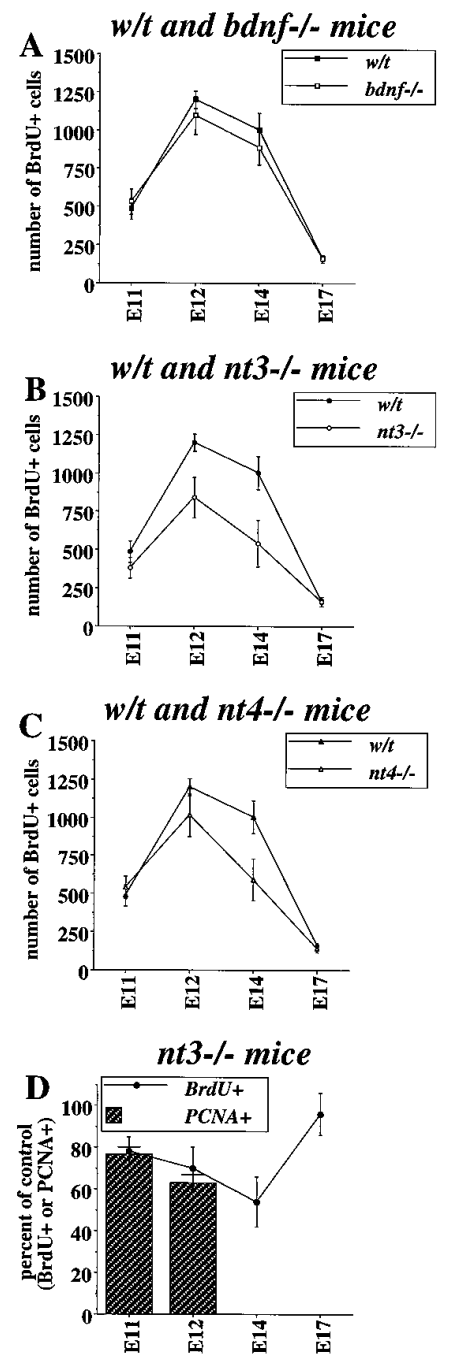

Figure 5. Number of proliferating cells in $(A) w / t$ and $b d n f^{-1-},(B) w / t$ and $n t 3^{-1-}$, and $(C) w / t$ and $n t 4^{-1-}$ N/P ganglia. Similar numbers of proliferating cells were found at all stages in $b d n f^{-1-}$ mice compared with $w / t(A)$. In $n t 3^{-1-}$ mice, a reduction in the number of proliferating cells was found at E12 and E14 compared with $w / t(B)$. In $n t 4^{-1-}$ mice, a reduction in the proliferating cells was seen only at E14 compared with $w / t$ (C). $D$, The percentage of $w / t \mathrm{BrdU}^{+}$(closed circle) or $\mathrm{PCNA}^{+}$cells (dashed bar) in the $n t 3^{-1-}$ mice at E11 and E12 compared with controls. Note the similar decrease in both $\mathrm{BrdU}^{+}$and $\mathrm{PCNA}^{+}$cells in the $n t 3^{-1-}$ mice at E11 and E12.

\section{DISCUSSION}

Mice carrying a deletion in the $b d n f, n t 3$, and $n t 4$ genes develop with severe deficits of neuronal numbers in the $\mathrm{N} / \mathrm{P}$ ganglion. In the present study we have examined in detail the $\mathrm{N} / \mathrm{P}$ ganglion neuron dependency on single and combinations of neurotrophins at a number of developmental stages to investigate how the neurotrophins collaborate in the generation of visceral neurons. We find that NT3 and NT4 act at early stages in the ganglion, at the height of neurogenesis and differentiation, whereas BDNF is crucial at later embryonic stages. The examination of different

Number of apoptotic cells measured in wild-type N/P ganglion (using the TUNEL method) after injection of $200 \mathrm{mg} / \mathrm{kg}$ (open bars, $n=4$ ) or 50 $\mathrm{mg} / \mathrm{kg}$ ( filled bars, $n=4$ ) BrdU. Note no significant change in the number of apoptotic cells between the two groups. 
Table 2. Number of $\mathrm{TH}^{+}$neurons at different stages in mutant mice

\begin{tabular}{|c|c|c|c|c|c|}
\hline & E12 & E14 & E17 & $\mathrm{P} 0$ & $\begin{array}{l}\text { Loss at } \\
\text { P0 }(\%)\end{array}$ \\
\hline$w / t$ & $132 \pm 26$ & $612 \pm 58$ & $594 \pm 99$ & $704 \pm 36$ & \\
\hline$b d n f^{-/-}$ & $144 \pm 12$ & $608 \pm 55$ & n.d. & $391 \pm 42$ & $45^{*}$ \\
\hline$n t 3^{-/-}$ & $123 \pm 45$ & $630 \pm 50$ & $560 \pm 75$ & $689 \pm 38$ & 2 \\
\hline$n t 4^{-/-}$ & $142 \pm 42$ & $666 \pm 89$ & n.d. & $646 \pm 51$ & 9 \\
\hline
\end{tabular}

Number of $\mathrm{TH}^{+}$neurons in the N/P ganglion at different developmental stages ( $\left.\pm \mathrm{SEM}\right)$. Only in the $b d n f^{-/-}$mice N/P ganglion was a significant reduction seen. n.d., Not determined. Student's $t$ test. ${ }^{*} p<0.05$.

Table 3. Number of $\mathrm{N} / \mathrm{P}$ ganglion neurons remaining in knockout or double-knockout mice at birth

\begin{tabular}{lcc} 
Genotype & $\begin{array}{l}\text { Total number } \\
\text { of neurons }\end{array}$ & $\begin{array}{l}\text { Percent of } \\
\text { wild type }\end{array}$ \\
\hline Wild type $(n=6)$ & $3976 \pm 294$ & 100 \\
$n t 3^{+/-}(n=4)$ & $2711 \pm 251$ & $68^{*}$ \\
$n t 3^{-/-}(n=6)$ & $2331 \pm 222$ & $59^{* *}$ \\
$b d n f^{+/-}(n=4)$ & $2590 \pm 145$ & $65^{*}$ \\
$b d n f^{-/-}(n=8)$ & $1645 \pm 194$ & $41^{* *}$ \\
$n t 4^{+/-}(n=2)$ & $3265 \pm 201$ & 82 \\
$n t 4^{-/-}(n=8)$ & $1651 \pm 357$ & $42^{* *}$ \\
$n t 3^{-/-} / b d n f^{-/-}(n=6)$ & $1340 \pm 145$ & $34^{*}$ \\
$b d n f^{+/-} / n t 4^{+/-}(n=4)$ & $2758 \pm 126$ & $69^{*}$ \\
$b d n f^{-/-} / n t 4^{-/-}(n=4)$ & $720 \pm 80$ & $18^{* *}$ \\
\hline
\end{tabular}

Number of N/P ganglion neurons at birth in $n t 3^{-/-}, b d n f^{-/-}$, and $n t 4^{-/-}$mice and double-mutant mice ( $\pm \mathrm{SEM}) . n=$ number of ganglia counted. Student's $t$ test. ${ }^{*} p<$ $0.05 ; * * p<0.01$.

combinations of double-knockout mice revealed that they act sequentially in a collaborative as well as a complementary manner during embryonic development. Our results argue for a switch of both NT3- and NT4-dependent neurons to BDNF at later stages, but also for the existence of neurons that depend only on NT3 or NT4. Corroborating our results are previous culture studies, which have shown the presence of sensory neurons that depend on neurotrophins in a developmental sequence (Buchman and Davies, 1993; Buj-Bello et al., 1994). However, only NGFdependent chick cranial ganglion neurons were shown to switch dependence from an early requirement of BDNF or NT3 (BujBello et al., 1994). A developmental switch of NT-4-dependent neurons to BDNF may have been difficult to examine in vitro because visceral neurons expressing the trkB receptor respond equally well in culture to BDNF and NT4, and these factors show no additive effects (Buj-Bello et al., 1994; Erickson et al., 1996). Thus, the above culture studies suggest that the trkB-expressing neurons cannot discriminate between BDNF and NT4 for their survival. The sequential action that we see in vivo could therefore be caused by spatially distinct expression of the ligands in the embryo. Hence, NT4 would be expressed locally at early stages, and BDNF would be expressed in the distal targets of nerve innervation at later stages. A local action of NT3 for early dorsal root ganglion neurons has been shown in the mouse (ElShamy and Ernfors, 1996a; Farinas et al., 1996), and at these stages NT3 is expressed in the close vicinity of the ganglion (Farinas et al., 1996; White et al., 1996).

What are the mechanisms underlying the switch in dependence of N/P ganglion neurons? In the dorsal root and trigeminal ganglion, trkA is expressed continuously in most neurons at both early and late stages, whereas trkC mRNA is downregulated in the majority of the neurons at later stages (Ernfors et al., 1992). At the corresponding time of development, cultured NT3dependent neurons switch in dependence to NGF (Buj-Bello et al., 1994). If this switch also occurs in vivo, it seems likely that the downregulation of $\operatorname{trkC}$ is crucial for the switch in the dorsal root ganglion and trigeminal ganglion. It is clear from our results that a switch in neurotrophin dependence occurs in the $\mathrm{N} / \mathrm{P}$ ganglion neurons in vivo. At early stages, most $\mathrm{N} / \mathrm{P}$ ganglion neurons express trkB, and only a subpopulation express trkC. Although trkB is persistently expressed throughout early and late development in most neurons, trkC mRNA is downregulated, and only a small percentage of the neurons continue to express it at later stages (Ernfors et al., 1992). This indicates that the downregulation of trkC is shared by all NT3-dependent early sensory neurons undergoing a switch in requirement, independent of whether the switch is to NGF or BDNF.

Both NT3 and NT4 act at early stages of the N/P ganglion development. In fact, they act before and during the time when most of the neurons are born (E12-E13 in the mouse) (also see Altman and Bayer, 1982) and could therefore be important for either immature neurons or precursor cells. A reduction in the number of proliferating cells was seen at E12-E14 in the $n t 3^{-/-}$ mice and at E14 in the $n t 4^{-1-}$ mice. Proliferation at stages later than E13 represents mostly the formation of the non-neuronal cells in the ganglion (Altman and Bayer, 1982). This raises the possibility that NT3, but not NT4, could act on neurogenic precursor cells of the $\mathrm{N} / \mathrm{P}$ ganglion. We and others have shown previously that NT3 is crucial for neurogenic precursors of the dorsal root ganglion during their last cell cycle (ElShamy and Ernfors, 1996a; Farinas et al., 1996). Because we detected TUNEL/BrdU and TUNEL/nestin (a marker of precursor cells) (Lendahl et al., 1990) double-stained cells, we concluded that NT3 is required for precursor cell survival (ElShamy and Ernfors, 1996a,b). Despite reporting similar results on cell number, proliferation, and rate of dying cells in the $n t 3^{-1-}$ dorsal root ganglion compared with our study (at E11, 89\%, 83\%, and 28\%, compared with our results of $85 \%, 84 \%$, and $18 \%$, respectively), Farinas et al. (1996) suggested that the absence of NT3 leads to a premature cell cycle exit of precursor cells. This conclusion was based on the detection of cells double-staining for TUNEL and neurofilament of $160 \mathrm{kDa}$ but the absence of TUNEL/BrdUpositive cells. It is not clear to us at this time whether precursor cells die or exit their cell cycle prematurely in the early dorsal root ganglion. However, if NT3 plays a role at the G1 phase of the cell cycle, just as growth factors do, it could generate a permissive condition for cells to either pass the cell cycle restriction point or to exit to Go. Thus, an absence of NT3 could lead to an abortive attempt to enter the cell cycle or could lead to premature cell cycle exit. In our view, it is therefore possible that an excess cell death of precursor cells and a premature cell cycle exit in the 
$n t 3^{-1-}$ mice are not mutually exclusive, but in fact could even be connected in the early dorsal root ganglion.

There is a massive final period of neurogenesis occurring between E12 and E13 in the mouse, at which time half of the N/P ganglion neurons are born. Because the deficits in BrdU incorporation and neuronal numbers in the $\mathrm{N} / \mathrm{P}$ ganglion of the $n t 3^{-/-}$ mice during the last days of neurogenesis resemble those reported previously in the dorsal root and trigeminal ganglia (ElShamy and Ernfors, 1996a,b), it is possible that NT3 has similar roles in all of these ganglia at early stages. In contrast to the $n t 3^{-1-}$ mice, the $n t 4^{-/-}$mice did not display deficits in BrdU incorporation at E11 or E12, suggesting that NT4 does not act on proliferating N/P ganglion precursors. Because most neurons are born shortly after E12, the marked and sudden loss of neurons between E12 and E14 in the $n t 4^{-1-}$ mice indicates that this factor could act on immature neurons.

We find that BDNF is required mostly at later stages, presumably as a target-derived factor. A target-derived role of BDNF should be represented by mRNA expression in visceral tissues. In agreement with such a role, BDNF mRNA as well as NT3 and NT4 mRNAs have been shown in many of the visceral tissues analyzed (Maisonpierre et al., 1990b; Timmusk et al., 1993). Interestingly, in the lung and heart, BDNF is developmentally upregulated, whereas NT4 mRNA levels remain at similar levels or are downregulated below the detection limit, respectively (Timmusk et al., 1993). In contrast to NT3 and NT4, there is now direct evidence that BDNF acts as a classical target-derived factor for N/P ganglion neurons. We recently showed that BDNF and NT3 are expressed in a nonoverlapping pattern in the tongue, and they support gustatory and somatosensory innervation, respectively (Nosrat et al., 1997). Thus, the gustatory neurons of the $\mathrm{N} / \mathrm{P}$ ganglion depend on BDNF produced in the target of innervation, the taste buds. Furthermore, the TH-positive neurons of the N/P ganglion that control ventilation also depend on BDNF (Erickson et al., 1996), and we find that normal numbers of TH-positive neurons are established independently of BDNF but perish soon thereafter. This result is consistent with a targetderived action of BDNF also for this functional population of $\mathrm{N} / \mathrm{P}$ ganglion neurons.

In conclusion, we find that NT3 is important for precursor cells during early stages of $\mathrm{N} / \mathrm{P}$ ganglion development. If it plays a similar role in the $\mathrm{N} / \mathrm{P}$ ganglion as in the dorsal root ganglion, it could stimulate their survival and/or retain the cells in the cell cycle. In either case the absence of NT3 leads to a reduced generation of neurons. Although NT4 may also act locally at early stages, it seems to act on immature neurons and does not influence the number of neurons born initially. Many, but not all, of the NT3- and NT4-dependent cells switch at later stages to needing BDNF from their targets of innervation. Among the neurons dependent on BDNF are the gustatory neurons innervating the taste buds and the chemoreceptive neurons innervating the carotid body. Our evidence for a coordinated action of three different neurotrophins that complement and collaborate during the establishment of the $\mathrm{N} / \mathrm{P}$ ganglion underscores the complex and highly specific neurotrophic interactions required in the development of the peripheral nervous system.

\section{REFERENCES}

Abercrombie (1946) Estimation of nuclear population from microtome sections. Anat Res 94:239-247.

Airaksinen MS, Koltzenburg M, Lewin GR, Masu Y, Helbig C, Wolf E, Brem G, Toyka KV, Thoenen H, Meyer M (1996) Specific subtypes of cutaneous mechanoreceptors require neurotrophin-3 following peripheral target innervation. Neuron 16:287-295.

Altman J, Bayer S (1982) Development of the cranial nerve ganglia and related nuclei in the rat. Adv Anat Embryol Cell Biol 74:1-90.

Arvidsson J, Rice FL, Fundin BT, Albers KM, Silos-Santiago I, Fagan AM, Barbacid M, Ernfors P, Davis BM (1995) Effects of NT-3 and TrkC manipulation on developing Merkel innervation in the mystacial pad of the mouse. Soc Neurosci Abstr, in press.

Barde Y-A, Edgar D, Thoenen H (1982) Purification of a new neurotrophic factor from mammalian brain. EMBO J 1:549-553.

Berkemeier L, Winslow J, Kaplan D, Nicolics K, Goeddel D, Rosental A (1991) Neurotropin-5: a novel neurotrophic factor that activates trk and trkB. Neuron 7:857-866.

Buchman VL, Davies AM (1993) Different neurotrophins are expressed and act in a developmental sequence to promote the survival of embryonic sensory neurons. Development 118:989-1001.

Buj-Bello A, Pinon CG, Davies AM (1994) The survival of NGFdependent but not BDNF-dependent cranial sensory neurons is promoted by several different neurotrophins early in their development. Development 120:1573-1580.

Coggeshall RE, Pover CM, Fitzgerald M (1994) Dorsal root ganglion cell death and surviving numbers in relation to the development of sensory innervation in the rat hindlimb. Dev Brain Res 82:193-212.

Conover JC, Erickson JT, Katz DM, Bianchi LM, Poueymirou WT, McClain J, Pan L, Helgren M, Ip NY, Boland P, Friedman B, Wiegand S, Vejsada R, Kato AC, DeCjira TM, Yancopolous GD (1995) Neuronal deficits, not involving motor neurons, in mice lacking BDNF and NT-4. Nature 375:235-238.

Davies A, Lindsay R (1985) The cranial sensory ganglia in culture: differences in the response of placode-derived and neural crest-derived neurons to nerve growth factor. Dev Biol 111:62-72.

ElShamy WM, Ernfors P (1996a) A local action of neurotrophin-3 prevents the death of proliferating sensory neuron precursor cells. Neuron 16:963-972.

ElShamy WM, Ernfors P (1996b) Requirement of neurotrophin-3 for the survival of proliferating trigeminal ganglion progenitor cells. Development 122:2405-2414.

Erickson JT, Conover JC, Borday V, Champagant J, Barbacid M, Yancopoulos G, Katz DM (1996) Mice lacking brain-derived neurotrophic factor exhibit visceral sensory neuron losses distinct from mice lacking NT4 and display a severe developmental deficit in control of breathing. J Neurosci 16:5361-5371.

Ernfors P, Ibanez CF, Ebendal T, Olson L, Persson H (1990) Molecular cloning and neurotrophic activities of a protein with structural similarities to nerve growth factor: developmental and topographical expression in the brain. Proc Natl Acad Sci USA 87:5454-5458.

Ernfors P, Merlio J-P, Persson H (1992) Cells expressing mRNA for neurotrophins and their receptors during embryonic rat development. Eur J Neurosci 4:1140-1158.

Ernfors P, Lee, K-F, Kucera J, Jaenisch R (1994a) Lack of neurotrophin-3 leads to deficiencies in the peripheral nervous system and loss of limb proprioceptive afferents. Cell 77:503-512.

Ernfors P, Lee K-F, Jaenisch R (1994b) Mice lacking brain-derived neurotrophic factor develop with sensory deficits. Nature 368:147-150.

Ernfors P, Van De Water TR, Loring J, Jaenisch R (1995) Complementary roles of BDNF and NT-3 in the auditory and vestibular development. Neuron 14:1153-1164.

Farinas I, Jones KR, Backus C, Wang XY, Reichardt LF (1994) Severe sensory and sympathetic deficits in mice lacking neurotrophin-3. Nature 369:658-661.

Farinas I, Yoshida CK, Backus C, Reichardt LF (1996) Lack of neurotrophin-3 results in death of spinal sensory neurons and premature differentiation of their precursors. Neuron 17:1965-1978.

Gaese F, Kolbeck R, Barde Y-A (1994) Sensory ganglia require neurotrophin-3 early in development. Development 120:1613-1619.

Gesine P, Davies AM (1995) Trigeminal sensory neurons require extrinsic signals to switch neurotrophin dependence during the early stages of target field innervation. Dev Biol 171:590-605.

Hallböök F, Ayer-LeLievre C, Ebendal T, Persson H (1990) Expression of nerve growth factor receptor mRNA during early development of the chicken embryo: emphasis on cranial ganglia. Development 108:693-704.

Harrison TA, Stadt HA, Kumiski D, Kirby ML (1995) Compensatory responses and development of the nodose ganglion following ablation 
of placodal precursors in the embryonic chick (Gallus domesticus). Cell Tissue Res 281:379-385.

Hertzberg T, Fan G, Finley JCW, Erickson JT, Katz DM (1994) BDNF support mammalian chemoafferent neurons in vitro and following peripheral target removal in vivo. Dev Biol 166:801-811.

Hohn A, Leibrock J, Bailey K, Barde YA (1990) Identification and characterization of a novel member of the nerve growth factor/brainderived neurotrophic factor family. Nature 344:339-341.

Hory-Lee F, Russel M, Lindsay RM, Frank E (1993) Neurotrophin-3 supports the survival of developing muscle sensory neurons in culture. Proc Natl Acad Sci USA 90:2613-2617.

Ip N, Ibanez C, Nye S, McClain J, Jones P, Gies D, Belluscio L, Le Beu M, Spinosa III M, Squinto R, Persson H, Yancopolous G (1992) Mammalian neurotrophin-4: structure, distribution and receptor specificity. Proc Natl Acad Sci USA 89:3060-3064.

Jones K, Reichardt L (1990) Molecular cloning of a human gene that is a member of the nerve growth factor family. Proc Natl Acad Sci USA 87:8060-8064.

Jones KR, Farinas I, Backus C, Reichardt LF (1994) Targeted disruption of the BDNF gene perturbs brain and sensory neuron development but not motor neuron development. Cell 76:989-999.

Kaisho Y, Yoshimura K, Nakahama K (1990) Cloning and expression of a cDNA encoding a novel human neurotrophic factor. FEBS Lett 266:187-191.

Kalcheim C, Carmeli C, Rosenthal A (1992) Neurotrophin-3 is a mitogen for cultured neural crest cells. Proc Natl Acad Sci USA 89:1661-1665.

Klein R, Silos-Santiago I, Smeyne RJ, Lira SA, Brambilla R, Bryant S, Zhang L, Snider WD, Barbacid M (1994) Disruption of the neurotrophin-3 receptor gene trkC eliminates la muscle afferents and results in abnormal movements. Nature 368:249-251.

Leibrock J, Lottspeich F, Hohn A, Hofer M, Hengerer B, Masiakowski P, Thoenen H, Barde YA (1989) Molecular cloning and expression of brain-derived neurotrophic factor. Nature 341:149-152.

Lendahl U, Zimmerman LB, McKay RDG (1990) CNS stem cells expression of new class of intermediate filament protein. Cell 60:585-595.

Levi-Montalcini R (1987) Nerve growth factor: thirty-five years later. EMBO J 6:1145-1154.

Lindsay RM, Rohrer H (1985) Placodal sensory neurons in culture: nodose ganglion neurons are unresponsive to NGF, lack NGF receptors but are supported by a liver-derived neurotrophic factor. Dev Biol 112:30-48.

Lindsay RM, Barde Y-A, Davies AM, Rohrer H (1985) Differences and similarities in the neurotrophic growth factor requirements of sensory neurons derived from neural crest and neural placode. J Cell Sci [Suppl] 3:115-129.

Liu X, Ernfors P, Wu H, Jaenisch R (1995) Sensory but not motor neuron deficits in mice lacking NT-4 and BDNF. Nature 375:238-240.

Maisonpierre PC, Belluscio L, Squinto S, Ip NY, Furth ME, Lindsay RM, Yancopolous GD (1990a) Neurotrophin-3: a neurotrophic factor related to NGF and BDNF. Science 247:1446-1451.

Maisonpierre PC, Belluscio L, Friedman B, Alderson RF, Wiegand SJ, Furth ME, Lindsay RM, Yancopolous GD (1990b) NT-3, BDNF and NGF in the developing rat nervous system: parallel as well as reciprocal patterns of expression. Neuron 5:501-509.

Memberg LP, Hall AK (1995) Proliferation, differentiation, and survival of rat sensory neuron precursors in vitro require specific trophic factors. Mol Cell Neurosci 6:323-335.

Morin X, Cremer H, Hirsch M-R, Kapur RP, Goridis C, Brunet J-F (1997) Defects in sensory and autonomic ganglia and absence of locus coeruleus in mice deficient for the homeobox gene Phox $2 \alpha$. Neuron 18:411-423.

Nosrat CA, Blomlöf J, ElShamy WM, Ernfors P, Olson L (1997) Lingual deficits in BDNF and NT3 mutant mice leading to gustatory and somatosensory disturbances, respectively. Development 124:1333-1342.

Oakley RA, Garner AS, Largge TH, Frank E (1995) Muscle sensory neurons require neurotrophin-3 from peripheral tissues during the period of normal cell death. Development 121:1341-1350.

Rosenthal A, V GD, Nguyen T, Lewis M, Shih A, Laramee GR, Nikolics K, Winslow JW (1990) Primary structure and biological activity of a novel human neurotrophic factor. Neuron 4:767-773.

Thaler CD, Suhr LA, Ip NY, Katz DM (1994) Leukemia inhibitory factor and neurotrophins support overlapping populations of nodose sensory neurons. Dev Biol 161:338-344.

Timmusk T, Belluardo N, Metsis M, Persson H (1993) Widespread and developmentally regulated expression of neurotrophin-4 mRNA in rat brain and peripheral tissue. Eur J Neurosci 117:1345-1353.

White FA, Silos-Santiago I, Molliver DC, Nishimura M, Phillips H, Barbacid M, Snider WD (1996) Synchronous onset of NGF and TrkA survival dependence in development of dorsal root ganglia. J Neurosci 16:4662-4672.

Wright EM, Vogel KS, Davies AM (1992) Neurotrophic factors promote the maturation of developing neurons before they become dependent on these factors. Neuron 9:139-150.

Yoshida Y, Yamada M, Wakabayyashi K, Ikuta F (1987) Immunohistochemical detection of DNA replicating cells in the developing nervous system: use of bromodeoxyuridine and its monoclonal antibody to rat foetuses. Biomed Res 8:431-444. 